\title{
ABSTRACTS \\ from \\ TRANSACTIONS published in JAPANESE
}

(Pages refer to the Japanese originals of this volume unless otherwise noted.)

\section{Enzymatic Studies on Cereals. (Part XIII).}

On the Change of the Amylase Action During the Ripening of Rice.

(pp. 677〜680)

By Gohei Yamagisi.

(Morioka Imperial College of Agriculture and Forestry;

Received August 11, 1941.)

In the previous papers of this series the author has declared that in the ungerminated rice-seeds there was in existence the water-insoluble zymogen amylase, which, at the germination, was decreased whereas the water-soluble amylase was increased.

Based on this fact, we are lead to suppose that during the ripening of rice the phenomena reverse to that of the germination may occur.

It is the purpose of this investigation to confirm whether this deduction is right or not, and the following results were obtained:

In the early stage of ripening the water-soluble amylase was most abundant, but afterwards that activity appeared to decrease gradually. The salt-soluble form of amylase, on the contrary, was increased as maturity advanced.

Of all amylases, this was so in the case of the saccharifying enzyme.

Thus, the author wants to claim that in the course of the ripening of the riceseeds some parts, at least, of the amylase are converted into an inactive zymogen form.

\section{On Xylitol. (3).}

Physical Properties of Xylitol.

(pp. 681 684)

By T. Yabuta, K. Aso, S. Kimoto, and K. Miwa.

(Agricultural Chemical Labolratoly, Tokyo Imperial University;

Recoived July 8, 1941,) 


\title{
Studies on "Tosetu," a Soy-bean Preparation. I. \\ On the Changes of Composition of Tosetu during its Manufacture and Storage. \\ (pp. 685 $\sim 690$ )
}

By K. Katai and B. Kitahara.

(Department of Agriculture, Kyüshū Imp. University and Nippon Yusi Kalusiki Kaisya ;

Received August 11, 1941.)

\section{Ascorbic Acid Content of Dried Peel, Canned Fruit and Juice of Satsuma Orange (Mandarin orange).}

(pp. 691 696)

\author{
By Yasuo Iwasaki and Toshio Komatsu. \\ (Institute of Rural Industry, Department of Agriculture and Forestry; \\ Received August 6, 1941.)
}

\section{Studies on Red Yeast. 1. Sporobolomyces nov. sp.}

(Report 3) Carotenoid Pigments in the Red Yeast

Sporobolomyces nov. sp.

(pp. $697 \sim 705$ )

By Izue Yamasaki, Seizi Morisita, and

Motomasa KAKEI.

(Agricultural Chemical Institute, Kyüshū Imperial University, Hukuoka;

Received August 11, 1941.)

The red color of the yeast Sporobolomyces is due to at least 7 pigments, separable by partition between different solvents and by chromatographic adsorption method.

Six of the pigments are neutral, one acidic.

In quantitative determination of three most abundant pigments, the yeast contains $23 \gamma \beta$-carotin, $92 \gamma$ torulin, $41.7 \mathrm{mg}$ of acidic pigment in $1 \mathrm{~g}$ dried yeast.

Of these, $12 \gamma \beta$-carotin was utilized as provitamin A by rats, $50 \gamma$ torulin and $100 \gamma$ of acidic pigment were useless.

Therefore it is confirmed that the yeast Spolobolomyces, contrary to the reports of previous authors, contains pro-vitamin $\mathrm{A}$ as does the red torula yeast.

Thanks are due to the Department of Education for a Scientific |Research Encouragement Grant. 


\section{On the Synthesis of Aspartic Acid. \\ (pp. $606 \sim 710$ ) \\ By Yoshio Tsuchiya. \\ (S. Suzuki and Co., I.td.; Received May 17, 1941.)}

The present author has prepared aspartic acid from fumaric acid $(1 \mathrm{~mol}$.$) ,$ ammonia ( 2 mol.) and ammonium chloride $(4 \mathrm{~mol}$.$) , by heating this mixture in$ autoclave $\left(180^{\circ}, 10 \mathrm{Atm}.\right)$ for 1 hour.

The yield of this amino acid was $60 \sim 65 \%$. A further $10 \%$ of aspartic acid was obtained from residual solution, which was obtain $d$ after the aspartic acid had been separated from the above reaction mixture by a similar treatment to that above mentioned.

\section{Functional Studies on Soil. (XXXII XXXVII).}

(pp. $711 \sim 720$ )

By Hideo Misu.

(Agricultural Experiment Station, Government General of Tyosen ;

Received May 13, 1941.)

\section{Biochemical Studies of "Bakanae" Fungus.}

Part 10. The Chemical Constitution of Gibberellin. I.

(pp. $721 \sim 730$ )

By T. Yabuta, Y. Sumiki, K.Aso, T. Tamura,

H. Igarasi, and K. TAMARI.

(Tokyo Imperial University; Received August 1, 1.941.)

\section{Zur Chemie des Muskeleiweisses.}

II. Mitteilung. Aminosäuregehalt des Kaninchenmuskeleiweisses.

(SS. $731 \sim 744$ )

Von M. Kandatu.

(Aus d. Agrikulturchem. Inst. d. Univers. Tokio, Japan:

Eingegangen am 23, 6. 1941,)

Das Muskeleiweiss der hinteren Extremitaten von etwa zweikilogrammigen Kaninchen wurde dreimal mit Methanol digeriert, dann mit Äther extrahiert. 
Von diesem gereinigten Muskeleiweiss wurde der Aminosäuregehalt nach der Brazier-Methode ermittelt.

Die Resultate sind folgende.

\begin{tabular}{l|c||c|c}
\multicolumn{1}{c|}{ Aminosäure } & $\begin{array}{c}\text { \% der trockenen } \\
\text { Masse }\end{array}$ & Aminosäure & $\begin{array}{c}\text { \% der trockenen } \\
\text { Masse }\end{array}$ \\
\hline Glykokoll & 4,2 & Oxyglutaminsäure & 1,5 \\
Alanin & 2,8 & Tyrosin & $* 4,3$ \\
Valin & 4,9 & Oxyprolin & 2,1 \\
Leucin & 12,0 & Arginin & 0,2 \\
Prolin & 7,7 & Histidin & 6,9 \\
Phenylalanin & 1,8 & Lysin & 1,1 \\
Asparaginsäure & 1,9 & Tryptophan & 9,6 \\
Glutaminsäure & 16,4 & & $* 1,8$ \\
\hline
\end{tabular}

* kalorimetrisch

\title{
Untersuchungen über das sogenannte , Glucono- bacter.“ I. Mitteilung.
}

(SS. 745 762)

Von Teijirô Uyfmura und Keiji Kondô.

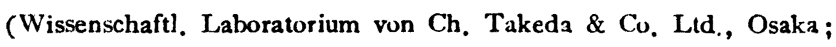

Eingegangen am 28. 4. 1941.)

\section{Biochemische Untersuchungen über die Bildung von Pflanzenbestandteilen.}

(SS. 763 770)

\author{
Von Yukihiko Nakamura und Tokuji Schimomura. \\ (Institut für Landwirtschaftliche Chemie, Iandwirtschaftliche Fakultät der \\ Kaiserlichen Hokkaido Universität: Eingegangen am 8. August 1941.)
}

Was für Bestandteile werden auf der ersten Stufe des Pflanzenwachstums erzeugt? Welche Beziehungen sind zwischen diesen Bestandteilen verschiedener Arten und dem weiteren Wachsen der Pflanzen vorhanden? Sind die auf diese Weise erzeugten Materialien der Zusammensetzung genau mit den bei der Vollendung des Wachstums gefundenen identisch oder nicht? Des weiteren wie steht es mit der Cellulose? Um diese Fragen zu beantworten, haben die Verfasser die jetzigen Untersuchungen angestellt. Als Versuchsmaterial haben sie sehr junge Stengel von Rapsen (japanisch „, Natane-Mojaschi “) gebraucht.

I. Mitteilung. Einer der Verfasser (Nakamura) hat folgende Ergebnisse beobachtet: Auch bei den auf der allerersten Stufe des Wachstums stehenden 
Pfianzen wie „Natane-Mojaschi “ konnten mit Sicherheit $a$-Cellulose bestimmt werden und überdies neben dem gro:3en Gehalt anorganischer Bestandteile auch stickstoffhaltige- und nichtstickstoffhaltige Verbindungen verschiedener Art, deren Polymerisationsgrade vielleicht kleiner zu sein scheinen, in großer Menge, und ferner konnten auch ätherlüsliche Substanzen in kleineren Mengen mit jenen zusammen vorkommen, aber des kleineren Gehaltes der letzteren wegen konnte die von Hess, Sisson und anderen vorgelegte Arbeitshypothese wohl nicht angenominen werden.

Die chenischen und physikalischen Eigenschaften der isolierten $a$-Cellulose und auch die der sonstigen Verbindungen sind noch nicht klar, werden aber gegenwärtig von den Verfassern erforscht.

II. Mitteilung. Die Verfasser haben qualitative Versuche von einigen hauptsächlichen Enzymen, die zweifellos bei der Bildung der Pflanzenmaterialien, d. h. dem Wachstum die wichtigste Rolle spielen müssen, gemacht.

Invertase, Amylase als Carbohydrase, pepsinartige-, trypsinartige Enzyme und Erepsin als eiweißspaltende Enzyme, Glycerophosphatase und wahrscheinlich auch Lipase als Esterase wurden in dieser Prüfung nachgewiesen, und außierdem wurde zugleich einige Aufmerksamkeit dem Gebrauch des Stalagmometers bei Untersuchung der Lipasewirkung zugewendet.

\title{
Separation and Identification of Fatty Acids. Part 6.
}

Preparation of Pure Linoleic and Linolenic Acids

by Means of Hydroxamic Acids Method.

(pp. $771 \sim 775$ )

\author{
By Y. Inouye and H. Yukawa. \\ (Biochemical Laboratory, Department of Agriculture, Kyoto Imperial University ; \\ Received August 22, 1941.)
}

The bromination-debromination procedure has been universally used for the isolation of linoleic and linolenic acids because it is the only method which yields products which are pure as evaluated by iodine number. This procedure involves bromination of natural tatty acid mixtures, purification of the solid tetra- or hexabrmides, and removal of bromine with zinc. Rollett originally carried out the debromination reaction with zinc in boiling strongly acidified alcohol. Recently Brown and his coworkers have shown that linoleic and linolenic acids, prepared by the debromination procedure, contain about 12 and $15 \%$, respectively, of isomeric acids which give nearly theoretical iodine numbers for $\mathrm{C}_{18}$, although their repeated low teniperature crystallization procedures for the isolation of these acids are, as they recognize, in a considerably less pure state than that which results from the debromination method.

The authors have studied the separation and identification of fatty acids as 
their hydroxamic acid derivatives which can be crystallized out and give acute melting points and from which free acids can be easily recovered by treating with mineral acid. This procedure should be remarked on the fact that, for the purpose of the separation of free pure acids, the chemical properties of double bond are not utilized at all, being different from the bromination-debromination procedure by which geometrical isomerizations have been discussed. The authors' process never comes in contact with double bonds in fatty acid molecule in the course of the preparation procedure, and consequently geometrical isomerizations at double bonds might be out of consideration.

The authors previously isolated crystalline linoleo- and linoleno-hydroxamic acids, the melting points being $41 \sim 42^{\circ} \mathrm{C}$ and $37 \sim 38^{\circ} \mathrm{C}$ respectively, from Rollett's linoleic and linolenic acids (This Journal, 16, 510, 1940.). In the present work the authors studied the isolation of linoleic acid directly from cotton seed and soya bean oils and linolenic acid from linseed oil. As results, it was concluded that this method may be recommendable as one of preparation methods of the above pure acids, in better yield than that of the bromination method. And besides this, the authors believe these investigations would be of some significance to a further identification of naturally occurred or prepared geometrical isomeric acids of the above acids, though the present studies were limited in the sense of ordinary linoleic and linolenic acids.

$44 \mathrm{~g}$ of cotton seed oil (saponification value, 190.66, mean mol. wt. 882.78, iodine value, 104.85) were treated two days at room temperature with $12.5 \mathrm{~g}$ of hydroxylamine hydrochloride and sodium ethylate $(7.6 \mathrm{~g}$ as sodium), using alcohol as solvent, and then neutralized to congo red with alcoholic hydrochloric acid at $0^{\circ} \mathrm{C}$. The process was tabulated as follows: The crystalline precipitates (a) were filtered off by suction and washed with ether and subsequently with water. $11.2 \mathrm{~g}$ (25\% of the oil) were obtained as precipitates which were hydroxamic acid mixtures of saturated fatty acids. The filtrate (A) was evaporated to syrup in vacuum, after being neutralized with sodium acetate and carbonate, and then again slightly acidified with alcoholic-glacial acetic acid and diluted with cold water to about 1 litre, following extraction with ether. The ether solution $(250 \mathrm{cc})$ was mixed with $100 \mathrm{cc}$ of petroleum ether and cooled down to $-5^{\circ} \mathrm{C}$. The precipitate (b) obtained mainly consisted of oleohydroxamic acid, with a small amount of linoleohydroxamic acid (O.1.) and the filtrate (B), after being evaporated to $250 \mathrm{cc}$ in vacuum, was mixed with $100 \mathrm{cc}$ of petroleum ether and cooled to $-5^{\circ} \mathrm{C}$. Thus the precipitate (c) and the filtrate (C) were obtained. The (c) was almost leaflet crystal which was confirmed to be mainly linoleohydroxamic acid, accompanied with a little amount of oleohydroxamic acid (L.o.). The (C) was condensed to dryness under reduced pressure and recrystallized twice from petroleum ether, and $14.5 \mathrm{~g}$ of crystals (33\% of the oil) were collected, the melting point being $41 \sim$ $42^{\circ} \mathrm{C}$ which was identified as the same as the linoleohydroxamic acid, previously prepared from the pure linoleic acid by the authors. And the free linoleic acid was quantitatively recovered by alcoholic sulphuric acid by the authors' usual 
method. The neutralization value, 199.73 and the iodine value, 178.9 of the free acid were determined.

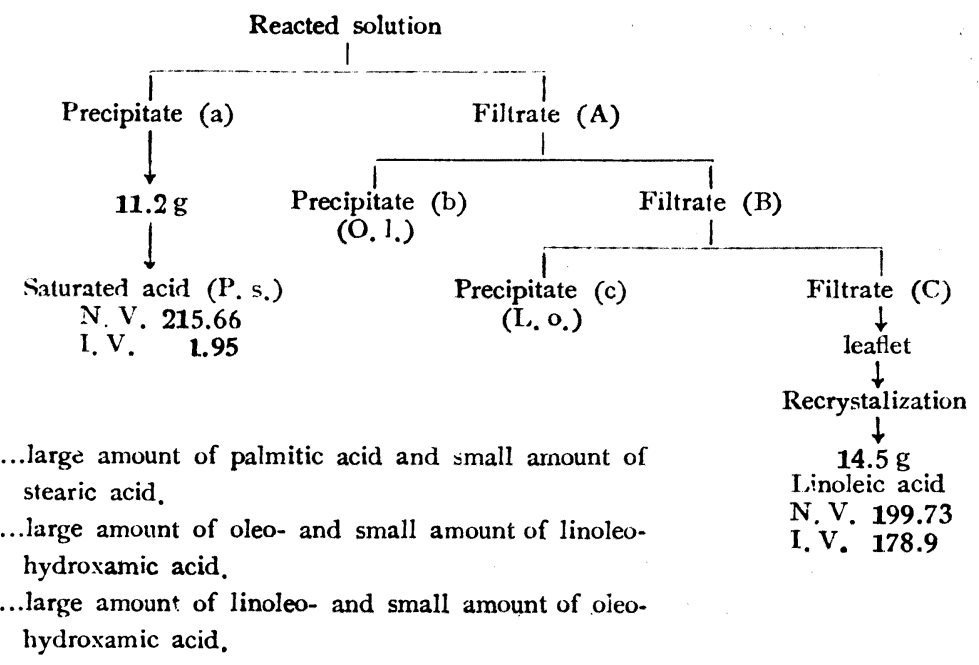

Almost the same result was obtained from soya bean oil (saponification value, 191.6, iodine value, 140.99). The yield of linoleohydroxamic acid to the oil was about $20 \%$.

The same procedure was applied to linseed oil (saponification value 189.66, mean mol. wt. 886.50, iodine value, 178.3) for the isolation of pure linolenic acid.

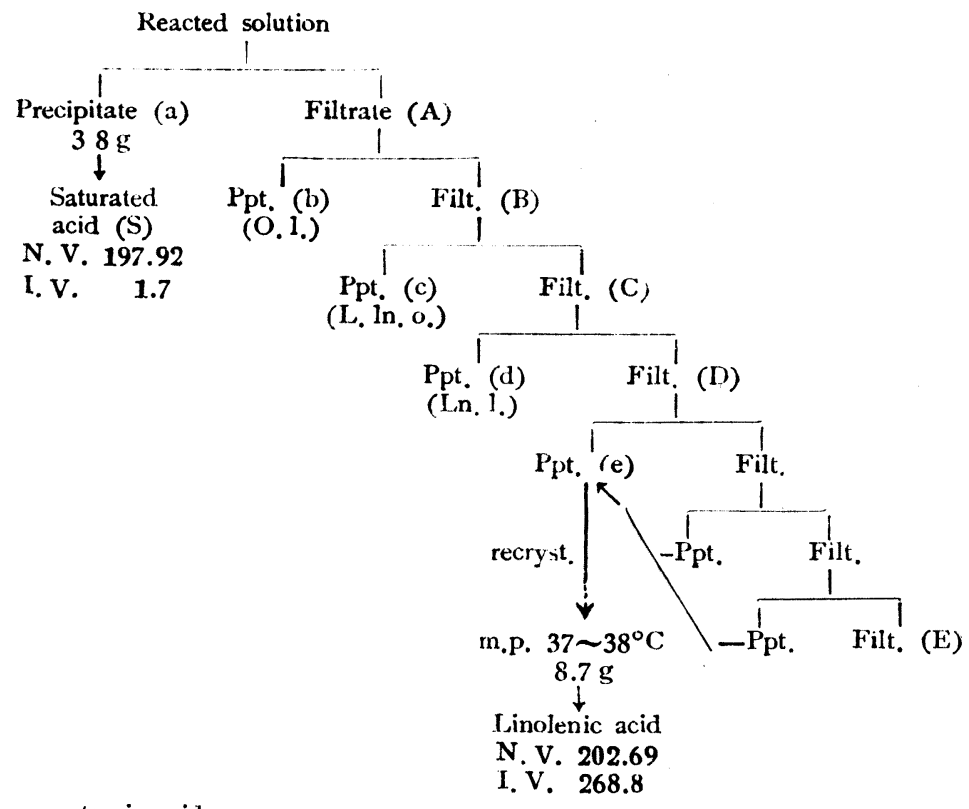

S ..............stearic acid

N. V. 202.69

O. 1............large amount of oleohydroxamic and small amount of linoleohydroxamic acid.

L. ln. o. ......large amount of linoleo- and small amount of linoleno- and oleohydroxamic acid.

L.n. 1. ........large amount of linoleno- and small amount of linoleohydroxamic acid. 
The schedule was tabulated as follows. $8.7 \mathrm{~g}$ of crystallized linolenohydroxamic acid (m.p. $37 \sim 38^{\circ} \mathrm{C}$ ) were obtained from $44 \mathrm{~g}$ of linseed oil.

The cost of this research has been defrayed from the Scientific Research Expenditure of the Department of Education to the authors' sincere gratitude.

\section{On the Chemical Studies of the Baggasse Pulp. (6). (pp. $776 \sim 778$ ) \\ By Tetutaro TAdokoro and Masao Nishida. \\ (Hokkaido Imperial University; Received July 29, 1941.)}

\section{Studies on the Components of the Bark of Rhamnus japonica (V).}

The Position of the Free Hydroxyl-group of $\boldsymbol{a}$-Sorinin.

(рp. $779 \sim 783$ )

By Zirô Nikuni.

(Agr. Chem. Laboratory, Tokyo Imp. Univ.; Received August 26, 1941.)

As reported previously, $a$-sorinin is a primveroside of $\boldsymbol{a}$-sorigenin ${ }^{(1)}$. The latter is the lactone of $x, x$-dihydroxy-x-methoxy-3-hydroxymethyl-2-naphthoic $\operatorname{acid}^{(2)}$. There is a wide difference between the characters of the two hydroxylgroups of $a$-sorigenin. Namely, the one shows characteristic greenish colour with ferric chloride solution and is methylated very easily by diazomethane. But the other shows no colour reaction with ferric chloride solution and is methylated with difficulty.

To determine which hydroxyl-group may be present in free state when it is the glycoside, $a$-sorinin (the glycoside) was methylated with diazomethane and then hydrolysed with dilute sulphuric acid. The resulting aglycone shows no colour reaction with ferric chloride solution and is identical with the monomethyl$a$-sorigenin ${ }^{(1)}$ obtained from $a$-sorigenin by methylation with diazomethane. It melts at $196 \sim 197^{\circ}$. So it is evident that the new methoxyl-group of monomethyla-sorigenin corresponds to the free hydroxyl-group of the glycoside.

On oxidation of $\alpha$-sorigenin and its derivatives by potassium permanganate, the following results are obtained.

(1) From $a$-sorigenin scarcely any oxidation products were obtained. It means that the two hydroxyl-groups are divided to different rings of the naphthalene nucleus.

(2) From monomethyl- $\alpha$-sorigenin faint yellowish prisms (m. p. 250 251 ${ }^{\circ}$ ) are obtained. From the analytical results, acidity and absorptionspectrum it is determined as monomethoxy-pyromellithic acid, which is a new compound. 
Analytical results :

$\begin{array}{lccc} & \mathrm{C} \% & \mathrm{H} \% & \mathrm{OCH}_{3} \% \\ \text { Observed } & 46.90 & 3.50 & 12.43 \\ \text { Calculated as } \mathrm{C}_{11} \mathrm{H}_{3} \mathrm{O}_{9} & 46.46 & 2.83 & 10.92\end{array}$

Acidity (titrated with $0.1 \mathrm{~N} \mathrm{HaOH}$ solution by microburette)

$\begin{array}{lr} & \mathrm{NaOH} \\ \text { Sample } 3.992 \mathrm{mg} & 2.286 \mathrm{mg} \\ \text { Calculated as } \mathrm{CH}_{3} \mathrm{O} \cdot \mathrm{C}_{6} \mathrm{H}(\mathrm{COOH})_{4} & 2.249 \mathrm{mg}\end{array}$

Thus it is clear that the new methoxyl-group of the monomethyl-a-sorigenin is present at the centre ring of the compound.

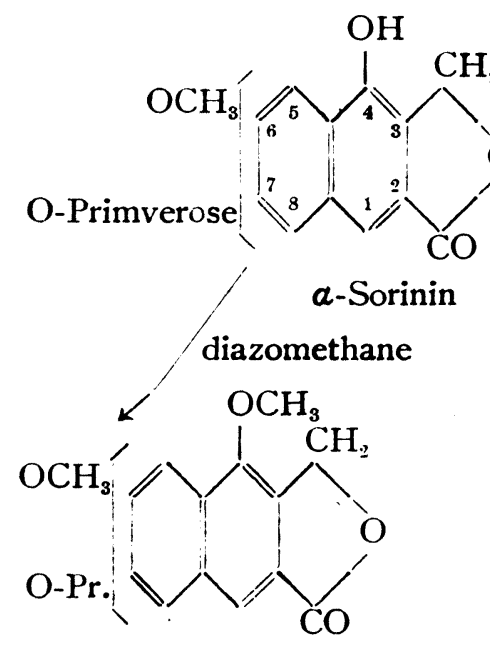

Methyl-a-sorinin

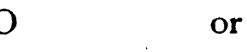

or<smiles>COc1ccc2cc3c(c(O)c2c1)C(=O)OC3</smiles><smiles>COc1ccc2cc(C=O)c(O)c(O)c2c1O</smiles>

a-Sorinin

(similarly)

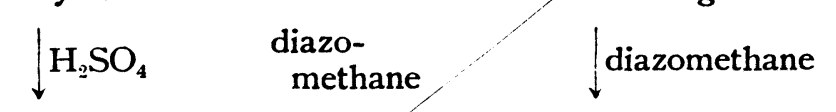

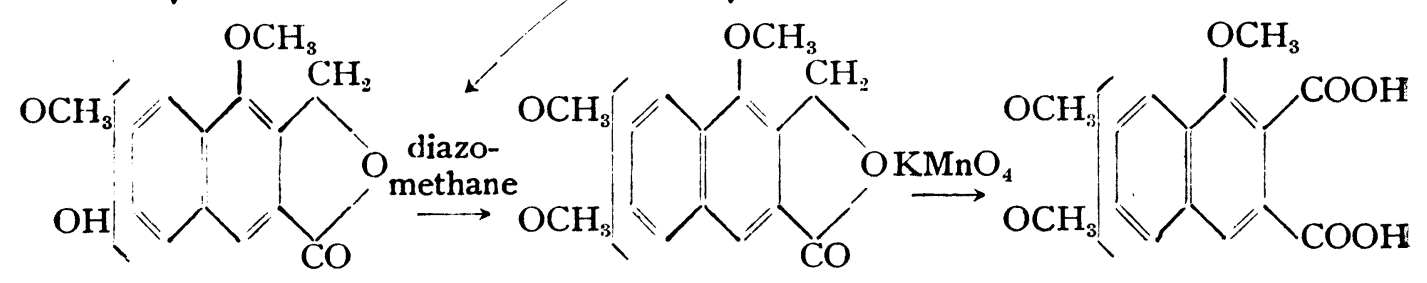

Monomethyl- $\alpha$-sorigenin

Dimethyl-a-sorigenin

Trimethoxy-naphthalenedicarboxylic acid

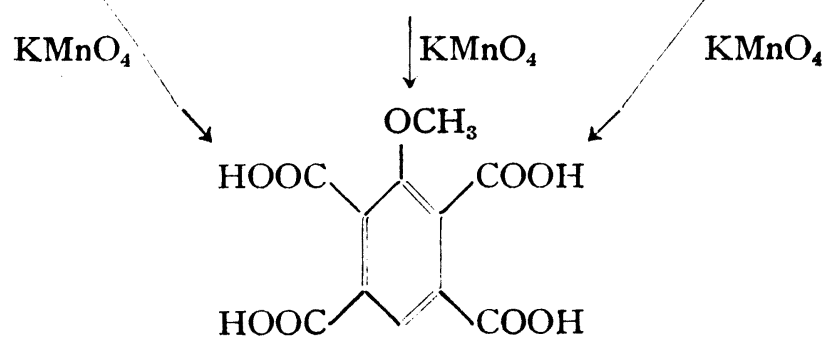

Monomethoxy-pyromellithic acid 
[Vol. 17,

(3) From dimethyl-a-sorigenin and trimethoxy-naphthalene-dicarboxylic $\operatorname{acid}^{(3)}$, monomethoxy-pyromellithic acid is also obtained, showing that the left side ring of these compounds is less stable than the centre ring.

$a$-Sorinin is therefore the lactone of $x$-primverosido- $x$-methoxyl-1 or 4-hydroxy3-hydroxymethyl-2-naphthoic acid.

The results are indicated as the figures (page 93):

In conclusion the author desires. to express his sincere thanks to Prof. Bunsuke Suzuki for his kind guidance throughout this work, and to the Imperial Academy for a grant, which has in part defrayed the cost of this investigation.

\section{Literature.}

(1) Nikuni: Bull. Agr. Chem. Soc. of Japan, 14, 25 (1938); C. 1938, II, 77

(2) Nikuni: ibid., 15, 43 (1939); C. 1939. II, 1292.

(3) Nikuni and Hayashi: ibid., 15, 158 (1939); C. 1940, I, 1996.

\section{Uber die Bestandteile der japanischen Mistel.}

III. Mitteilung. Oleanolsäure, zwei Harzalkohole ( $\beta$-Amyrin u. Lupeol) in den Blättern.

(SS. 784 786)

Von Yataro OвAтA.

(Biochemiches Institut der Landwirtschaftlichen Fakuităt, Universităt Tokio :

Eingegangen am 22. 8. 1941.) 